\title{
ANALISIS PENGARUH BELANJA LANGSUNG, BELANJA TIDAK LANGSUNG DAN INVESTASI SWASTA TERHADAP KEMISKINAN DI KOTA BITUNG
}

\author{
Teddy Desly Minggu $u^{1}$,Veckie A. Rumate ${ }^{2}$, Debby Ch. Rotinsulu ${ }^{3}$ \\ Fakultas Ekonomi dan Bisnis, Magister Ilmu Ekonomi \\ Universitas Sam Ratulangi, Manado
}

\begin{abstract}
ABSTRAK
Pengeluaran pemerintah daerah melalui belanja langsung maupun belanja tidak langsung merupakan alat intervensi pemerintah terhadap perekonomian yang dianggap paling efektif selama ini. Investasi dapat menjadi titik tolak bagi keberhasilan dan keberlanjutan pembangunan di masa depan karena dapat menyerap tenaga kerja, sehingga dapat membuka kesempatan kerja baru bagi masyarakat yang pada gilirannya akan berdampak terhadap peningkatan pendapatan masyarakat, dan akhirnya akan menurunkan tingkat kemiskinan.

Nilai koefisien sebesar - 0.1941 yang signifikan menunjukkan bahwa perkembangan Jumlah Penduduk Miskin (JPM) di Kota Bitung memiliki hubungan yang negatif dengan berubahnya Belanja Langsung (BL). Dengan perkataan lain, selama periode yang diteliti, dengan menjaga agar variabel-variabel lain tetap, 1 persen peningkatan dalam BL akan mengakibatkan pengurangan/penurunan rata-rata sekitar 0.1941 persen Jumlah Penduduk Miskin (JPM).

Nilai koefisien sebesar - 0.0075, menunjukkan bahwa perkembangan jumlah penduduk miskin (JPM) di Kota Bitung memiliki hubungan yang negatif dengan meningkatnya BTL. Dengan perkataan lain, selama periode penelitian, dengan menjaga agar variabel-variabel lain tetap (ceteris paribus), 1 persen peningkatan dalam BTL akan mengakibatkan penurunan rata-rata sekitar 0.0075 persen dalam JPM.

Nilai koefisien sebesar - 0.0589 menunjukkan bahwa JPM di Kota Bitung memiliki hubungan yang negatif dengan bertambahnya Investasi swasta (INV). Hal ini menunjukkan bahwa dengan bertambahnya INV akan mengurangi Kemiskinan (JPM) di Kota Bitung. Dengan perkataan lain, selama periode penelitian, dengan menjaga agar variabelvariabel lain tetap, 1 persen peningkatan dalam INV akan mengakibatkan penurunan rata-rata sekitar 0.0589 persen JPM di Kota Bitung.
\end{abstract}

Kata Kunci: Belanja Daerah, Investasi, Kemiskinan

\section{ABSTRACT}

Spending by local government through direct and indirect spending is a means of government intervention in the economy that are considered most effective for this. Investing can be a starting point for the success and sustainability of development in the future because it can create employment, so as to open up new employment opportunities for the community, which in turn will impact on the increase in people's income, and will ultimately reduce the level of poverty.

The coefficient value of - 0.1941 Significant suggests that the development Poverty rates (JPM) in the city of Bitung has a negative correlation with the change in direct expenditure (BL). In other words, during the period under study, by keeping other variables remain, a 1 percent increase in the BL will lead to a reduction / average decline of about 0.1941 percent Poverty rates (JPM).

The coefficient value of - 0.0075, indicating that the increase in the number of poor people (JPM) in the city of Bitung has a negative correlation with the increase in BTL. In other words, during the study period, by keeping other variables fixed (ceteris paribus), a 1 percent increase in BTL will lead to a decline on average of about 0.0075 percent of the $J P M$.

The coefficient value of - 0.0589 indicates that JPM in Bitung City has a negative correlation with the increase in private investment (INV). This shows that with increasing INV will reduce poverty (JPM) in the city of Bitung. In other words, during the study period, by keeping other variables remain, a 1 percent increase in INV will result in an average decline of about 0.0589 percent of JPM in Bitung.

Keywords: Local Expenditure, Investment, Poverty

\section{PENDAHULUAN}

\section{Latar belakang masalah.}

Kemiskinan telah menjadi persoalan global yang kompleks dan tak kunjung usai, sebab kemiskinan merupakan fenomena yang terjadi hampir di semua negara sedang berkembang. Termasuk di Indonesia, 
dimana kemiskinan merupakan masalah yang bersifat multidimensi dan multi sektor yang menyangkut harkat dan martabat manusia. Banyak dampak negatif yang disebabkan oleh kemiskinan, selain timbulnya banyak masalah-masalah sosial, kemiskinan juga dapat mempengaruhi pembangunan ekonomi suatu negara. Kemiskinan yang tinggi akan menyebabkan biaya yang harus dikeluarkan untuk melakukan pembangunan ekonomi menjadi lebih besar, sehingga secara tidak langsung akan menghambat pembangunan ekonomi. Persoalan kemiskinan menjadi salah satu target kebijakan pembangunan di setiap negara. Untuk mengatasi kemiskinan diperlukan berbagai upaya pembangunan dan kebijakan yang mendukung pelaksanaan pembangunan tersebut.

Pembangunan harus dilihat sebagai proses multidimensi yang mencakup tidak hanya pembangunan ekonomi, namun juga mencakup perubahan-perubahan utama dalam struktur sosial, perilaku, dan kelembagaan. Tujuan utama pembangunan ekonomi selain berupaya untuk menciptakan pertumbuhan yang setinggi-tingginya, pembangunan harus pula berupaya untuk menghapus atau mengurangi tingkat kemiskinan, ketimpangan pendapatan dan tingkat pengangguran atau upaya menciptakan kesempatan kerja bagi penduduk sebab dengan kesempatan kerja masyarakat akan memperoleh pendapatan untuk memenuhi kebutuhan hidupnya (Todaro, 2000).

Untuk membangun suatu daerah maka diperlukan pembiayaan baik melalui pengeluaran pemerintah maupun dari sektor swasta. Pembangunan setidaknya mempunyai tiga dimensi pokok yaitu terciptanya pertumbuhan ekonomi, penanggulangan kemiskinan dan transformasi struktural perekonomian. Dari ketiga hal tersebut maka pertumbuhan ekonomi dan kemiskinan menjadi isu sentral, karena dengan adanya pertumbuhan ekonomi maka masalah kemiskinan dapat diatasi.

Masalah yang banyak dihadapi oleh seluruh daerah dalam pelaksanaan desentralisasi fiskal yaitu kemiskinan. Hal ini menjadi masalah baik pada daerah perkotaan maupun pedesaan karena banyaknya masyarakat yang masih memiliki kemampuan rendah dalam membuka lapangan pekerjaan dan tidak banyak peluang masyarakat untuk mendapat pekerjaan serta banyaknya pekerja yang di-PHK karena para pengusaha kekurangan modal dan gulung tikar. Banyak upaya yang sudah dilakukan untuk menanggulagi kemiskinan yang terjadi namun upaya tersebut masih belum cukup dalam upaya mengentaskan kemiskinan. Dalam RPMJD Kota Bitung 2011-2016, kemiskinan merupakan salah satu fokus utama pembangunan di kota Bitung, sehingga program kegiatan diarahkan untuk menanggulangi masalah kemiskinan. Kalau dilihat dari persentase jumlah penduduk miskin dari tahun ketahun mengalami fluktuasi, walaupun trendnya cenderung menurun. Kenaikan dan penuruan persentase penduduk miskin setiap tahunnya di kota Bitung merupakan suatu kondisi yang perlu di kaji mengapa hal tersebut terjadi, sehingga kebijakan yang nantinya dikeluarkan oleh pemerintah daerah benar-benar tepat dan dapat menyelesaikan permasalahan yang ada. perkembangan kependudukan Kota Bitung dari tahun 2004-2014 terus mengalami peningkatan, namun pada tahun 2006 terjadi penurunan sebesar 0,1 persen dari tahun 2005. Mengingat kota Bitung adalah kota industri maka pertumbuhan penduduk di kota Bitung terbesar dipengaruhi oleh faktor migrasi, sehingga kalau pada tahun 2006 terjadi penurunan maka pada saat itu jumlah penduduk yang meninggal (angka kematian) lebih besar dibandingkan dengan angka kelahiran atau jumlah migrasi yang masuk ke kota Bitung. Demikian juga dengan penduduk miskin tahun 2004-2007 juga mengalami peningkatan, tapi pada tahun 2008-2009 mengalami penurunan, namun pada tahun 2010 kembali meningkat, dan diempat tahun terakhir dari 2011-2014 kembali mengalami penurunan. Kalau dilihat dengan pengeluaran pemerintah daerah (belanja langsung dan Belanja tidak langsung) pada kondisi tersebut juga mengalami kondisi yang fluktuatif, dimana untuk belanja langsung pada tahun 2005 terjadi penurunan dari Rp. 111,395,709,977 menjadi Rp. 109,993,740,874, demikian juga untuk belanja langsung terjadi penurunan yang sangat signifikan pada tahun 2007 yaitu sebesar Rp. 79,396,280,670 atau terjadi penurunan sebesar Rp. 46. 024.388.036, dari Rp.125,420,668,706 pada tahun 2006, sehingga hal ini menarik untuk dikaji lebih jauh.

Kebijakan pemerintah daerah dalam bentuk kebijakan fiskal melalui pengeluaran pemerintah daerah berupa belanja langsung dan belanja tidak langsung diharapkan dapat menanggulangi masalah kemiskinan sehingga angka kemiskinan di kota Bitung terus mengalami penurunan. Belanja daerah, atau yang dikenal dengan pengeluaran pemerintah daerah dalam anggaran pendapatan dan belanja daerah (APBD), merupakan salah satu faktor pendorong pertumbuhan ekonomi daerah. Karena itu, belanja daerah dikenal sebagai salah satu instrumen kebijakan fiskal yang dilakukan pemerintah (pemerintah daerah), di samping pos pendapatan pemerintah daerah. 
Semakin besar belanja daerah diharapkan akan makin meningkatkan kegiatan perekonomian daerah (terjadi ekspansi perekonomian) dan pada akhirnya akan meningkatkan kesejahteraan masyarakat dan tentunya akan mengurangi kemiskinan. Di sisi lain, semakin besar pendapatan yang dihasilkan dari pajakpajak dan retribusi atau penerimaan-penerimaan yang bersumber dari masyarakat, maka akan mengakibatkan menurunnya kegiatan perekonomian (terjadi kontraksi perekonomian.

Hakikat Anggaran Pendapatan Belanja Daerah (APBD) yang disusun oleh pemerintah daerah adalah harus dapat meningkatkan kesejahteraan masyarakat di wilayahnya, sehingga setiap belanja dalam program dan kegiatan yang direncanakan dalam APBD harus bertumpu pada hal tersebut. Belanja Daerah merupakan bagian utama dalam APBD yang berkaitan dengan peran pemerintah dalam meningkatkan kesejahteraan masyarakat. Dalam peraturan menteri dalam negeri nomor 13 tahun 2006 tentang pengelolaan keuangan daerah pengeluaran pemerintah daerah (belanja) di kelompokan menjadi dua yaitu belanja langsung dan belanja tidak langsung. Pengeluaran pemerintah daerah melalui belanja langsung maupun belanja tidak langsung merupakan alat intervensi pemerintah terhadap perekonomian yang dianggap paling efektif.

Keberhasilan suatu daerah dalam mewujudkan kesejahteraan masyarakat sangat tergantung pada kebijakan pemerintah daerah melalui alokasi belanjanya. Alokasi belanja yang baik tentunya diharapkan dapat meningkatkan kesejahteraan masyarakatnya. Pemerintah daerah kota Bitung dalam menjalankan kebijakan anggarannya tentunya tetap mengacu pada ketentuan-ketentuan yang ada tentang pengelolaan keuangan daerah. Baik mulai dari proses perencanaan program dan kegiatan bahkan sampai pelaksanaan program kegiatan tetap berpedoman pada ketentuan yang ada. Perkembangan belanja tidak langsung dari tahun 2005 mengalami penurunan dibandingkan dengan tahun 2004, tahun 2006-2007 mengalami peningkatan dan di tahun 2008 terjadi penurunan kembali dan sejak 2009-2014 terus mengalami peningkatan. Sama halnya juga dengan belanja langsung pada tahun 2005 mengalami peningkatan jika dibandingkan dengan tahun 2004, namun di tahun 2007 mengalami penurunan yang sangat signifikan dari Rp.125,420,668,706 turun menjadi Rp.79,396,280,670, dan di tahun selanjutnya dari 2008 sampai dengan tahun 2014 terus mengalami peningkatan. Kalau disandingkan dengan jumlah penduduk miskin atau persentase kemiskinan di kota Bitung yang juga mengalami fluktuasi, maka tentunya sangat menarik untuk dikaji lebih jauh mengapa hal ini terjadi dan bagaimana hubungannya dan pengaruhnya. Kota Bitung yang dikenal sebagai kota industri perekonomiannya sangat tergantung dari sektor industri, baik itu industri perikanan maupun industri agro serta industri lainnya. Investasi di kota Bitung terdiri dari investasi dalam negeri maupun investasi dari luar negeri (PMDN dan PMA). Perkembangan investasi dalam negeri maupun luar negeri sangat cepat sehingga hal ini tentunya membawa dampak yang positif bagi kesejahteraan masyarakat yang ada di kota Bitung.

Berdasarkan latar belakang diatas maka penting untuk diteliti bagaimana pengaruh belanja langsung, belanja tidak langsung dan investasi swasta terhadap kemiskinan di kota Bitung.

\section{Perumusan Masalah.}

Berdasarkan latar belakang permasalahan yang telah diuraikan diatas, maka yang menjadi permasalahan dalam penelitian ini adalah:

1. Bagaimana pengaruh belanja langsung terhadap kemiskinan di Kota Bitung?

2. Bagaimana pengaruh belanja tidak langsung terhadap kemiskinan di Kota Bitung?

3. Bagaimana pengaruh investasi swasta terhadap kemiskinan di Kota Bitung?

\section{Tujuan Penelitian.}

Adapun yang menjadi tujuan penelitian ini adalah:

1. Untuk menganalisis pengaruh belanja langsung terhadap kemiskinan di Kota Bitung.

2. Untuk menganalisis pengaruh belanja tidak langsung terhadap kemiskinan di Kota Bitung

3. Untuk menganalisis pengaruh investasi swasta terhadap kemiskinan di Kota Bitung

\section{Manfaat Penelitian.}

Penelitian ini diharapkan dapat bermanfaat :

- Sebagai bahan informasi bagi pemerintah daerah dan pihak-pihak yang memerlukannya untuk bahan pertimbangan dan masukan dalam merumuskan prioritas dan arah kebijakan pembangunan daerah. 
- Sebagai referensi atau masukan bagi peneliti, untuk penelitian lebih lanjut.

\section{LANDASAN TEORI}

\section{Pengeluaran/belanja pemerintah}

Salah satu komponen dalam permintaan agregat (aggregate demand [AD]) adalah pengeluaran pemerintah. Mankiw (2000) menyatakan bahwa jika pengeluaran pemerintah meningkat maka AD akan meningkat. Selain itu, peranan pengeluaran pemerintah $(G)$ di negara berkembang sangat signifikan mengingat kemampuan sektor swasta untuk mendorong pertumbuhan ekonomi masih sangat terbatas. Oleh karena itu, peranan pemerintah sangatlah penting. Peningkatan AD berarti terjadi pertumbuhan ekonomi, karena pertumbuhan ekonomi diukur dari PDB maka peningkatan pertumbuhan berarti peningkatan pendapatan. Terdapat berbagai instrumen yang digunakan pemerintah untuk mempengaruhi perekonomian, salah satu diantaranya adalah pembelanjaan atau pengeluaran pemerintah. Dalam model pembangunan tentang perkembangan pengeluaran pemerintah yang dikembangkan oleh Rostow dan Musgrave (Mangkoesoebroto, 2001) bahwa pada tahap awal perkembangan ekonomi, persentase investasi pemerintah terhadap total investasi sangat besar. Hal ini disebabkan oleh karena pada tahap ini pemerintah harus menyediakan prasarana. Peranan pemerintah tetap besar pada tahap menengah oleh karena peranan swasta yang semakin besar ini banyak menimbulkan kegagalan pasar.

Dalam konteks perekonomian negara sedang berkembang, peranan kebijakan fiskal adalah untuk memacu laju pembentukan modal. Kebijakan fiskal juga memainkan peranan penting di dalam rencana pembangunan negara terbelakang. Di dalam perencanaan, suatu keseimbangan harus dicapai baik dalam arti riil maupun dalam arti uang. Dengan kata lain, rencana fisik harus disesuaikan dengan rencana keuangan. Penerapan rencana keuangan dan pencapaian perimbangan dalam arti riil dan keuangan jelas banyak tergantung pada tindakan-tindakan fiskal (Jhingan,473).

Pengeluaran pemerintah merupakan komponen relatif kecil dibanding komponen lain dalam penghitungan pertumbuhan ekonomi. Walau demikian, pengeluaran pemerintah mempunyai efek sosial politis yang strategis sebagai fungsi alokasi, distribusi, maupun stabilisasi. Selain itu, pengeluaran pemerintah pun mempunyai efek multiplier terhadap ekonomi makro riil dalam pergerakan jangka pendek dari output dan ketenagakerjaan (Samuelson \& Nordhaus, 1996).

Peraturan menteri dalam negeri nomor 13 Tahun 2006 telah menentukan, struktur belanja terdiri dari belanja tidak langsung, dan belanja langsung. Belanja tidak langsung merupakan belanja yang dianggarkan tidak terkait secara langsung dengan pelaksanaan program dan kegiatan yang meliputi: belanja pegawai, belanja bunga, belanja subsidi, belanja hibah, bantuan sosial, belanja bagi hasil, bantuan keuangan, dan belanja tidak terduga.

Sedangkan belanja langsung merupakan belanja yang dianggarkan terkait secara langsung dengan pelaksanaan program dan kegiatan yang meliputi: belanja pegawai, belanja barang dan jasa, serta belanja modal. Belanja tidak langsung adalah pengeluaran yang tidak dikaitkan secara langsung dalam program atau kegiatan (Haryanto, 2013). Belanja tidak langsung diarahkan kepada pelayanan dasar seperti pendidikan, kesehatan dan ketersediaan pelayanan umum untuk meningkatkan kesejahteraan masyarakat. Hal ini bertujuan untuk masyarakat mendapat pelayanan yang lebih baik. Tujuan utama dalam alokasi belanja tidak langsung adalah kemiskinan yang ada di daerah. Kajian yang meneliti hubungan belanja pemerintah dengan kemiskinan dilakukan oleh Merdekawati dan Budiantara (2013) yang menyatakan bahwa, pengalokasian belanja daerah untuk bantuan sosial berpengaruh positif terhadap penurunan persentase kemiskinan. Hal ini menandakan alokasi belanja daerah untuk bantuan sosial yang dilakukan pemerintah sudah tepat sasaran dan berjalan dengan baik dalam mengurangi kemiskinan di daerah. Menurut Suryadarma dan Suryahadi (2007) menyatakan bahwa pertumbuhan pengeluaran barang publik dan swasta akan menurunkan kemiskinan lebih cepat apabila mengandalkan belanja publik.

\section{Investasi}

Investasi merupakan komponen sangat penting dalam pembangunan ekonomi. Dari beberapa komponen percepatan pertumbuhan ekonomi seperti akumulasi modal, pertumbuhan penduduk, dan kemajuan teknologi, investasi sebagai akumulasi modal menjadi faktor dominan dalam memperbaiki dan melipatgandakan kualitas sumber daya fisik dan sumber daya manusia (Todaro \& 
Penelusuran Harrod-Domar terhadap model pertumbuhan ekonomi di negara maju menemukan bahwa akumulasi investasi dan tabungan nasional merupakan faktor penentu pertumbuhan ekonomi. Hal ini berkait dengan karakteristik investasi sebagai akselerasi dalam menciptakan pendapatan yang juga disebut dampak permintaan, serta proses multiplier dalam memperbesar akumulasi modal yang juga disebut dampak penawaran.

Teori ekonomi mengartikan atau mendefinisikan investasi sebagai pengeluaran-pengeluaran untuk membeli barang-barang modal dan peralatan peralatan produksi dengan tujuan untuk mengganti dan terutama menambah barang-barang modal dalam perekonomian yang akan digunakan untuk memproduksikan barang dan jasa di masa depan". Menurut Boediono (1992) investasi adalah pengeluaran oleh sektor produsen (swasta) untuk pembelian barang dan jasa untuk menambah stok yang digunakan atau untuk perluasan pabrik. Dornbusch \& Fischer berpendapat bahwa investasi adalah permintaan barang dan jasa untuk menciptakan atau menambah kapasitas produksi atau pendapatan di masa mendatang.

Menurut Sadono Sukirno (2012) kegiatan investasi memungkinkan suatu masyarakat terus menerus meningkatkan kegiatan ekonomi dan kesempatan kerja, meningkatkan pendapatan nasional dan meningkatkan taraf kemakmuran masyarakat. Peranan ini bersumber dari tiga fungsi penting dari kegiatan investasi, yakni (1) investasi merupakan salah satu komponen dari pengeluaran agregat, sehingga kenaikan investasi akan meningkatkan permintaan agregat, pendapatan nasional serta kesempatan kerja; (2) pertambahan barang modal sebagai akibat investasi akan menambah kapasitas produksi; (3) investasi selalu diikuti oleh perkembangan teknologi.

Adhisasmita (2005), mengemukakan bahwa investasi atau perpindahan modal (swasta maupun pemerintah) merupakan sarana bagi proses kumulatif, mengarah ke atas di daerah yang bernasib baik dan mengarah ke bawah di daerah yang bernasib tidak baik. Di daerah perkotaan yang sedang mengalami perkembangan, kenaikan permintaan akan mendorong pendapatan dan permintaan, yang selanjutnya menaikkan investasi, dan demikian seterusnya. Di daerah-daerah lainnya dimana perkembangan sangat lamban maka permintaan terhadap modal untuk investasi adalah rendah sebagai akibat dari rendahnya penawaran modal dan pendapatan yang cenderung makin rendah. Perbedaan perkembangan tersebut dan terkonsentrasinya investasi di daerah-daerah yang mapan mengakibatkan terjadinya ketimpangan atau bertambahnya ketidakmerataan.

Menurut Samuelson dan Nordhaus (1996), investasi merupakan suatu hal yang penting dalam pembangunan ekonomi karena investasi ini dibutuhkan sebagai faktor penunjang didalam peningkatan proses produksi.

Dengan demikian investasi diartikan sebagai pengeluaran atau pembelanjaan penanam-penanam modal atau perusahaan untuk membeli barang-barang modal dan perlengkapan-perlengkapan produksi untuk menambah kemampuan memproduksi barang dan jasa yang tersedia dalam perekonomian, sehingga investasi disebut juga dengan penanaman modal. (Sukirno, 2011). Investasi ini memiliki peran aktif dalam menentukan tingkat output, dan laju pertumbuhan output tergantung pada laju investasi (Arsyad, 1999). Lebih lanjut, Jhingan (2004) menyebutkan salah satu efek kegiatan investasi pada sisi permintaan agregat yang mempengaruhi pendapatan bila investasi meningkat maka pengeluaran agregat akan meningkat, yang kemudian meningkatkan pendapatan daerah melalui proses multiplier.

Untuk mendapatkan gambaran mengenai perkembangan investasi dari waktu ke waktu, ada tiga macam cara (berdasarkan tiga gugus data) yang bisa dilakukan (Dumairy,1996). Pertama, dengan menyoroti kontribusi pembentukan modal domestik bruto dalam konteks permintaan agregat, yakni dengan melihat sumbangan atau perkembangan variabel investasi dalam persamaan pendapatan nasional, $\mathrm{Y}=\mathrm{C}+\mathrm{I}+\mathrm{G}+\mathrm{X}-\mathrm{M}$. Data investasi merupakan data keseluruhan investasi domestik bruto, meliputi baik investasi oleh swasta (PMDN dan PMA) Kedua, ialah dengan mengamati data PMDN dan PMA, dimana dengan cara ini berarti hanya mengamati investasi oleh kalangan dunia usaha swasta saja. Ketiga, adalah dengan menelaah perkembangan dana investasi yang disalurkan oleh dunia perbankan. Cakupan data dengan cara ini relatif lebih terbatas, karena belum memperhitungkan modal sendiri yang ditanam oleh investor.

Investasi swasta di Indonesia dijamin keberadaannya sejak dikeluarkannya Undang-Undang No.25 Tahun 2007 tentang Penanaman Modal. Berdasarkan sumber dan kepemilikan modal, maka investasi swasta dibagi menjadi penanaman modal dalam negeri dan asing. Dengan semakin besarnya investasi pemerintah pada barang publik maka diharapkan akan mendorong pertumbuhan sektor pertumbuhan sektor 
swasta dan rumah tangga dalam mengalokasikan sumberdaya yang ada di suatu daerah. Hal ini pada akhirnya akan menyebabkan makin meningkatnya PDRB.

\section{Kemiskinan}

Kemiskinan merupakan suatu kondisi ketidakmampuan secara ekonomi untuk memenuhi standar hidup rata-rata masyarakat di suatu daerah. Fenomena seperti ini biasa terjadi dikarenakan rendahnya pendapatan masyarakat dalam memenuhi kebutuhan pokok baik papan, sandang, maupun pangan dan juga rendahnya kualitas sumber daya manusia itu sendiri. Kemampuan pendapatan yang rendah ini juga akan berdampak pada berkurangnya kemampuan untuk memenuhi standar hidup rata-rata seperti standar kesehatan dan standar pendidikan. Masalah kemiskinan sering terjadi di negara berkembang yang memiliki tingkat penduduk yang tinggi sehingga terjadi ketidakmerataan kesejahteraan masyarakat yang dapat memicu ketimpangan sosial.

Kemiskinan menurut Mudrajad Kuncoro (2000) adalah ketidakmampuan untuk memenuhi standar hidup minimum. Permasalahan standar hidup yang rendah berkaitan pula dengan jumlah pendapatan yang sedikit, perumahan yang kurang layak, kesehatan dan pelayanan kesehatan yang buruk, tingkat pendidikan masyarakat yang rendah sehingga berakibat pada rendahnya sumber daya manusia dan banyaknya pengangguran. Tingkat standar hidup dalam suatu negara bisa diukur dari beberapa indikator antara lain Gross National Product (GNP) per capita, pertumbuhan relatif nasional dan pendapatan per kapita, distribusi pendapatan nasional, tingkat kemiskinan, dan tingkat kesejahteraan masyarakat.

Todaro (2006) menjelaskan bahwa kemiskinan dapat diukur dengan atau tanpa mengacu kepada garis kemiskinan (poverty line). Konsep yang mengacu kepada garis kemiskinan disebut kemiskinan absolut, sedangkan konsep yang pengukurannya tidak didasarkan pada garis kemiskinan disebut kemiskinan relatif. Kemiskinan absolut didefinisikan sebagai ketidakmampuan pemenuhan sumberdaya pokok untuk kesejahteaan, termasuk makanan, air, perumahan, tanah, kesehatan dan pendidikan. Sementara kemiskinan relatif merupakan kondisi yang disebabkan oleh kebijakan pembangunan yang belum dapat menjangkau masyarakat secara merata sehingga menyebabkan ketimpangan distribusi pendapatan.

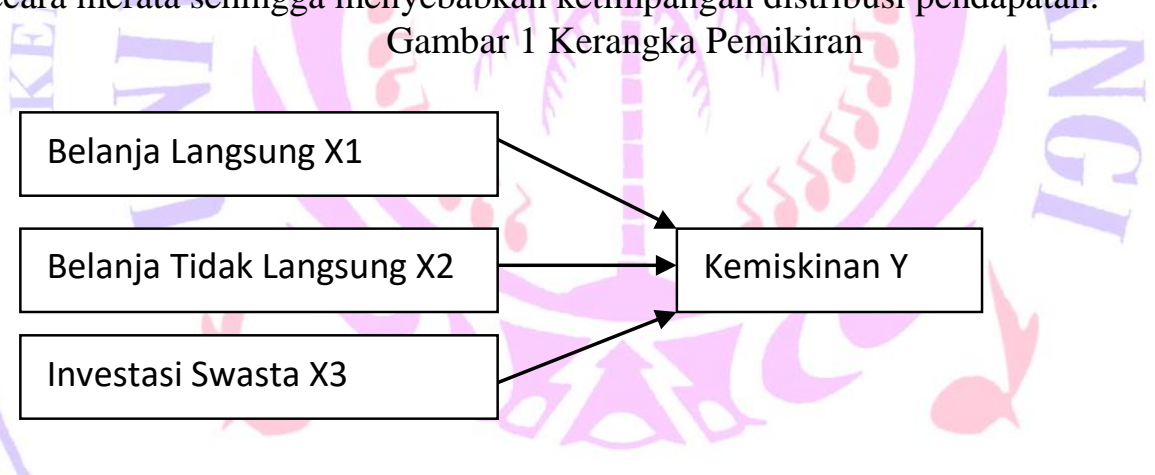

\section{METODE PENELITIAN}

\section{Jenis Data dan Sumber Data}

Data yang digunakan dalam penelitian ini adalah data sekunder dengan jenis data time series periode tahun 2006-2014, yang bersumber dari:

- Badan Pusat Statistik (BPS) Kota Bitung

- Badan Pengelola Keuangan dan Barang Milik Daerah Kota Bitung

- Badan Pelayanan Perijinan Terpadu Kota Bitung

- Badan Perencanaan dan Pembangunan Daerah (BAPPEDA) Kota Bitung

\section{Definisi dan Pengukuran Variabel.}

Untuk menyamakan persepsi tentang vaiabel-variabel yang digunakan dan menghindari terjadinya perbedaan tafsiran, maka penulis memberi batasan definisi operasional sebagai berikut: 
- Kemiskinan (JPM) adalah jumlah penduduk miskin absolut menurut kriteria Badan Pusat Statistik (BPS) di Kota Bitung selama periode tahun 2004-20014. Menurut BPS Jumlah penduduk miskin adalah jumlah keseluruhan populasi dengan pengeluaran per kapita berada di bawah ambang batas tertentu yang dinyatakan sebagai garis kemiskinan. Garis kemiskinan adalah nilai rupiah pengeluaran perkapita setiap bulan untuk memenuhi standar minimum kebutuhan-kebutuhan konsumsi pangan dan non pangan yang dibutuhkan oleh seorang individu untuk hidup secara layak (BPS, 2007). Kebutuhan minimum makanan menggunakan patokan 2.100 kalori/hari, kebutuhan non makanan meliputi perumahan, sandang, aneka barang dan jasa. Satuan dari variabel kemiskinan adalah dalam jiwa.

- Belanja Langsung (BL) adalah merupakan belanja yang dianggarkan terkait secara langsung dengan pelaksanaan program dan kegiatan yang meliputi: belanja pegawai, belanja barang dan jasa, serta belanja modal yang ada pada APBD Kota Bitung periode tahun 2004 sampai dengan tahun 2014 dalam satuan rupiah.

- Belanja Tidak Langsung (BTL) adalah merupakan belanja yang dianggarkan tidak terkait secara langsung dengan pelaksanaan program dan kegiatan yang meliputi: belanja pegawai, belanja bunga, belanja subsidi, belanja hibah, bantuan sosial, belanja bagi hasil, bantuan keuangan, dan belanja tidak terduga yang ada pada APBD Kota Bitung periode tahun 2004 sampai dengan tahun 2014 dalam satuan rupiah.

- Investasi adalah nilai dari penanaman modal baik asing maupun dalam negeri yang dilakukan oleh investor di Kota Bitung kurun waktu 2004 sampai dengan 2014 dalam rupiah.

\section{Metode Analisis}

Metode analisis yang digunakan dalam penelitian ini untuk mengetahui pengaruh Belanja Langsung, Belanja Tidak Langsung dan Investasi terhadap Jumlah Penduduk Miskin di Kota Bitung adalah Analisis Regresi Berganda dimana analisis regresi ini dikenal sebagai analisis Ordinary Least Square (OLS). Dalam penelitian ini menggunakan data time series tahun 2006-2014. Kemiskinan (Jumlah Penduduk Miskin) dijadikan sebagai variabel dependen (tidak bebas) sedangkan Belanja Langsung, Belanja Tidak Langsung dan Investasi dijadikan variabel independen (bebas) yang diformulasikan yang ditunjukkan pada persamaan (1).

$$
\begin{aligned}
& \text { JPM }=\mathrm{f}(\mathrm{BTL}, \mathrm{BL}, \mathrm{INV}) \\
& \text { dimana } \\
& \mathrm{JPM}=\text { Jumlah Penduduk Miskin } \\
& \mathrm{BTL}=\text { Belanja Tidak Langsung } \\
& \mathrm{BL} \quad=\text { Belanja Langsung } \\
& \mathrm{INV}=\text { Investasi Swasta }
\end{aligned}
$$

Dari model fungsional persamaan (1) dapat ditulis secara model ekonometrika sebagai berikut dimana,

$$
\mathrm{JPM}_{\mathrm{t}}=\beta_{0}+\beta_{1} \mathrm{BTL}_{\mathrm{t}}+\beta_{2} \mathrm{BL}_{\mathrm{t}}+\beta_{3} \mathrm{INV}_{\mathrm{t}}+\mathrm{e}_{\mathrm{t}}
$$

JPM = Jumlah Penduduk Miskin

BTL = Belanja Tidak Langsung

BL $\quad=$ Belanja Langsung

INV = Investasi Swasta

$\beta_{0} \quad=$ konstanta (intersep)

$\beta_{1}, \beta_{2}, \beta_{3}=$ koefisien regresi dari masing-masing variabel bebas,

$\mathrm{e} \quad=$ error term

$\mathrm{t} \quad=$ sampel 9 tahun (tahun 2006-2014)

Persamaan (2) ditransformasikan kedalam bentuk log-natural seperti yang ditunjukkan persamaan (3). Pentransformasian ke dalam bentuk log-natural bertujuan untuk menjadikan nilai variabel-variabel yang dianalisis menjadi seimbang dan juga sekaligus hasil output regresi menunjukkan koefisien slope merupakan tingkat perubahan variabel tidak bebas (dalam persen) bila terjadi perubahan variabel-variabel bebas (dalam persen) Nachrowi, (2006). dimana,$$
\mathrm{LJPM}_{\mathrm{t}}=\beta_{0}+\beta_{1} \mathrm{LBTL}_{\mathrm{t}}+\beta_{2} \mathrm{LBL}_{\mathrm{t}}+\beta_{3} \mathrm{LINV}_{\mathrm{t}}+\mathrm{e}_{\mathrm{t}}
$$ 


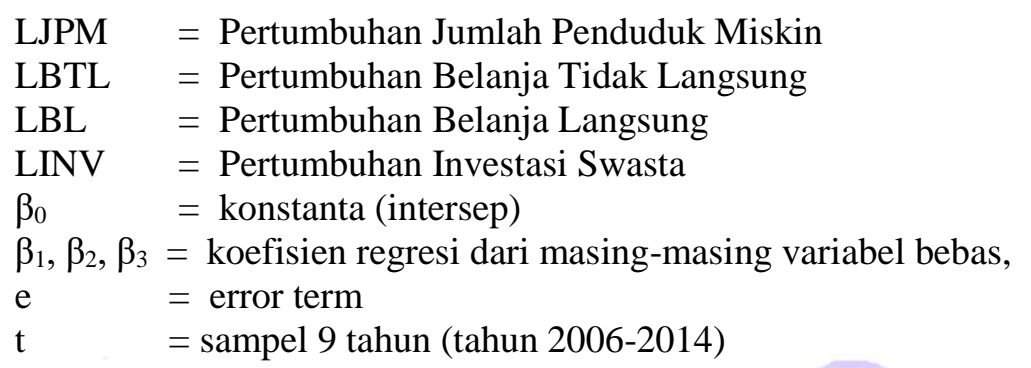

\section{Pengujian Statistik}

Dalam melakukan penelitian, untuk keabsahan suatu model perlu dilakukan pengujian-pengujian statistik. Menurut Gujarati (2003), hal ini perlu dilakukan agar suatu model tidak diragukan lagi.

\section{Uji F-statistik}

Uji F digunakan untuk mengetahui apakah variabel-variabel independen dalam persamaan regresi tersebut mempengaruhi variabel dependen secara bersamaan dengan tingkat signifikansi tertentu. Formula yang digunakan untuk Uji F-statistik ditunjukan oleh persamaan (4).

$$
F=\frac{R^{2} /(k-1)}{\left(1-R^{2}\right) /(n-k)}
$$

Keterangan :

$$
\begin{array}{ll}
\mathrm{F} & =\text { signifikan hubungan kedua variabel } \\
\mathrm{R}^{2} & =\text { koefisien determinasi } \\
\mathrm{n} & =\text { banyaknya pengamatan } \\
\mathrm{k} & =\text { jumlah variabel yang diamati }
\end{array}
$$

Perumusan hipotesis

Dalam persamaan ekonometrik berupa suatu regresi Ordinary Least Square (OLS), perumusan hipotesis perlu dilakukan untuk menguji kebenaran korelasi variabel-variabel independen yang mempengaruhi variabel dependen secara bersamaan. Adapun perumusannya sebagai berikut:

$$
\text { Ho : } \beta 1=\beta 2=\beta 3=0
$$

(tidak ada pengaruh yang berarti antara variabel independen terhadap variabel dependen)

$$
\mathrm{Ha}: \beta 1, \beta 2, \beta 3 \neq 0
$$

(ada pengaruh variabel independen terhadap variabel dependen)

Kriteria pengujian

Kriteria pengujian menggunakan uji hipotesis nol (null hypothesis)

$$
\text { Ho tidak ditolak jika } \mathrm{F}_{\text {hitung }}<\mathrm{F}_{\text {tabel }}
$$

Ho tidak ditolak berarti variabel yang diuji secara keseluruhan tidak mempunyai pengaruh yang berarti terhadap kemiskinan.

Ho ditolak apabila $\mathrm{F}_{\text {hitung }}>\mathrm{F}_{\text {tabel }}$

Ho ditolak berarti variabel yang diuji secara keseluruhan mempunyai pengaruh yang berarti terhadap kemiskinan.

\section{Uji t-statistik}

Untuk mengetahui apakah variabel independen mempunyai pengaruh terhadap variabel dependen secara parsial, maka dilakukan uji t. Formula yang digunakan untuk Uji t-statistik ditunjukan oleh persamaan (5).

$$
t=\frac{\hat{\beta}_{i}-\beta_{i}}{S E\left(\hat{\beta}_{i}\right)}
$$


Keterangan :

$\hat{\beta}_{\mathrm{i}}=$ hasil estimasi

$\beta_{\mathrm{i}}=$ parameter sesuai dengan hipotesis Ho

$\operatorname{se}\left(\beta_{\mathrm{i}}\right)=$ standar error regresi

Perumusan hipotesis

Ho : $\beta_{1}=0$ (tidak ada pengaruh secara berarti dari perubahan dari masing-masing variabel bebas terhadap variabel tidak bebas).

Hi $: \beta_{1} \neq 0 \quad$ (ada pengaruh secara berarti dari perubahan dari masing-masing variabel bebas terhadap variabel tidak bebas).

Kriteria pengujian

Bila $-\mathrm{t}_{\text {tabel }}<\mathrm{t}_{\text {hitung }}<\mathrm{t}_{\text {tabel }}$ maka Ho tidak ditolak dan menolak Hi

Berarti variabel independen secara individual tidak berpengaruh terhadap variabel dependen

Jika $t_{\text {hitung }}>t_{\text {tabel }}$ dan $t_{\text {hitung }}<-t_{\text {tabel }}$ maka Ho ditolak dan Hi tidak ditolak

Berarti variabel independen secara individual berpengaruh terhadap variabel dependen

\section{Koefisien Determinasi}

Dalam pengukuran ketepatan suatu garis regresi digunakan koefisien determinasi $\left(\mathrm{R}^{2}\right)$. Koefisien determinasi $\left(\mathrm{R}^{2}\right)$ yaitu angka yang menunjukkan besarnya derajat kemampuan menerangkan variabel bebas terhadap variabel tak bebas dari fungsi tersebut. Nilai $\mathrm{R}^{2}$ berkisar $0<\mathrm{R}^{2}<1$ dimana semakin mendekati 1 maka semakin dekat pula hubungan antara variabel bebas dengan variabel tak bebas, atau dapat dikatakan model tersebut baik, demikian pula sebaliknya.

\section{Uji Model}

Pengujian regresi linier berganda dapat dilakukan setelah model dari penelitian ini memenuhi syarat-syarat yaitu lolos dari asumsi klasik. Syarat-syarat yang harus dipenuhi adalah data tersebut harus terdistribusikan secara normal, tidak mengandung multikoloniaritas, dan heterokedastisitas. Untuk itu sebelum melakukan pengujian regresi linier berganda perlu dilakukan lebih dahulu pengujian asumsi klasik, yang terdiri dari:

\section{Uji Normalitas}

Pengujian normalitas memiliki tujuan untuk menguji apakah dalam model regresi, variabel penganggu atau residual memiliki distribusi normal. Seperti diketahui bahwa uji t mengasumsikan bahwa nilai residual mengikuti distribusi normal. Kalau asumsi ini dilanggar maka uji statistik menjadi tidak valid untuk jumlah sampel kecil. Untuk menguji normalitas data, penelitian ini menggunakan Jarque-Berra Test. Dari hasil Jarque-Berra Test, jika probality value lebih besar dari $\alpha=0.05(5 \%)$ maka data berdistribusi normal.

\section{Uji Multikolinearitas}

Multikolineariti dapat diartikan sebagai hubungan linear diantara beberapa atau semua variabel independen dalam sebuah model regresi. Uji ini diperlukan agar CLRM ( Classical Linear Regression Model ) terpenuhi, yaitu suatu kondisi dimana terdapat hubungan yang linear sempurna di antara beberapa atau semua variabel independen dalam sebuah model regresi. Multikolineariti dapat dideteksi apabila nilai $\mathrm{R}^{2}$ yang tinggi dan uji-F yang signifikan, tetapi banyak koefisien regresi dalam uji-t yang tidak signifikan, Nachrowi (2006). Pendeteksian adanya multikolineariti dapat juga dengan cara menghitung koefisien korelasi antar variabel independen, Winarno (2007). Dalam penelitian ini, uji multikolinearitas dilakukan dengan menggunakan kaidah "Corelation Matrix". Penggunaan kaidah ini dilakukan dengan cara melihat keofisien antara variabel bebas. Jika koesien korelasi diantara masing-masing variabel bebas lebih besar 0,8, maka terjadi Multikolinearitas.

\section{Uji Heteroskedastisitas}

Salah satu asumsi yang harus dipenuhi agar taksiran parameter dalam model regresi bersifat BLUE maka semua residual error mempunyai varian yang sama. Kondisi seperti itu disebut dengan homokedastis. Sedangkan bila varian tidak konstan atau berubah-ubah disebut heterokedastis. Untuk mendeteksi adanya 
masalah heterokedastisitas akan digunakan uji-formal, yaitu uji-White yang telah tersedia dalam program siap pakai Eviews. Dari hasil uji-White, jika nilai probality value lebih rendah dari $\alpha=0.05(5 \%)$ berarti terdapat Heterokedastisitas.

\section{Uji Autokorelasi}

Pada penelitian in menggunakan Langrange Multiplier Test (LM Test) untuk mengetahui adanya autokorelasi dalam model regresi. Autokorelasi adalah korelasi antar anggota serangkaian observasi yang diurutkan menurut waktu (seperti dalam data deretan waktu) atau ruang (seperti dalam data cross sectional). Jika hasil estimasi nilai probality value lebih rendah dari $\alpha=0.05(5 \%)$ menunjukkan bahwa hasil estimasi tersebut adalah signifikan, bahwa terdapat autokorelasi.

\section{HASIL PENELITIAN DAN PEMBAHASAN}

\section{Hasil Regresi Model}

Model Kemiskinan yang digunakan dalam penelitian ini menjadikan variabel Kemiskinan (Jumlah Penduduk Miskin) sebagai variabel tidak bebas, dan yang menjadi variabel bebas yaitu Belanja Langsung (BL), Belanja Tidak Langsung (BTL) dan Investasi Swata (INV). Estimasi dilakukan dengan metode Ordinary Least Square. Model tersebut dengan hasil estimasinya ditunjukkan pada persamaan 6.

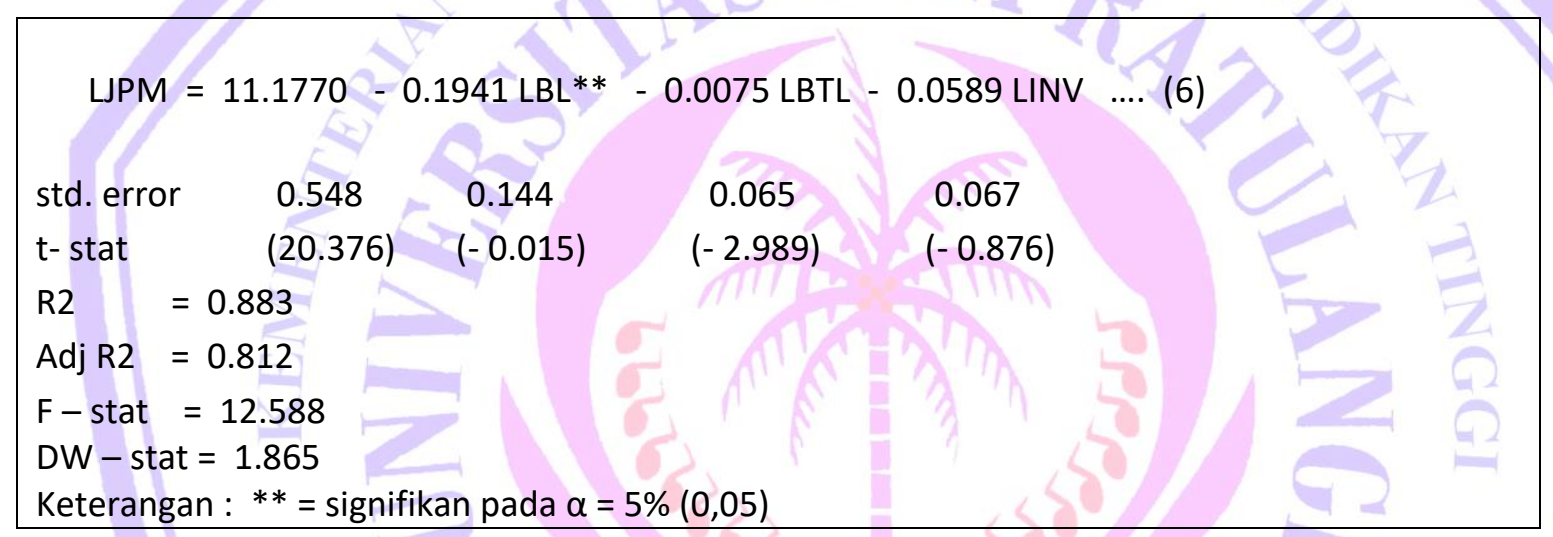

\section{Pengujian Statistik}

\section{Uji t-stat}

Dari hasil perhitungan yang telah diperoleh dilakukan pengujian t-hitung/statistik untuk mengetahui bagaimana pengaruh tiap-tiap variabel bebas secara parsial terhadap Kemiskinan di Kota Bitung. Hipotesis dari uji ini adalah sebagai berikut,

Ho : $\beta_{1}=0$, variabel bebas tidak mempengaruhi variabel tak bebas

Hi : $\beta_{1} \neq 0$, variabel bebas mempengaruhi variabel tak bebas

Dengan menguji dua arah dalam tingkat signifikansi (Confidence Level atau $C L$ ) dan derajat kebebasan (degree of freedom $)=(\alpha, n-k)$, dimana $\alpha$ menunjukkan tingkat kepercayaan analisis, $n$ menunjukkan jumlah observasi, dan k menunjukkan jumlah parameter termasuk konstanta, hasil pengujian akan menghasilkan dua kesimpulan menurut hipotesis di atas:

Bila $-\mathrm{t}_{\text {tabel }}<\mathrm{t}_{\text {hitung }}<\mathrm{t}_{\text {tabel }}$ maka Ho tidak ditolak dan menolak Hi

Berarti variabel bebas secara individual tidak berpengaruh terhadap variabel tak bebas

Jika $\mathrm{t}_{\text {hitung }}>\mathrm{t}_{\text {tabel }}$ dan $\mathrm{t}_{\text {hitung }}<-\mathrm{t}_{\text {tabel }}$ maka Ho ditolak dan Hi tidak ditolak

Berarti variabel bebas secara individual berpengaruh terhadap variabel dependen

\section{Variabel Belanja Langsung (BL)}

Dari hasil estimasi model Kemiskinan, maka diperoleh nilai t-statistik untuk variabel Belanja Langsung (BL) yaitu sebesar - 2.989 . 


\begin{tabular}{cccc} 
Ho ditolak & \multicolumn{1}{c}{ Ho tidak ditolak } & Ho ditolak \\
\hline-2.989 & -2.571 & |
\end{tabular}

Apabila dibandingkan dengan nilai t tabel, maka dapat dilihat bahwa nilai t-hitung variabel ini lebih kecil dari batas kiri t-tabelnya dengan ketentuan $\mathrm{df}_{(\alpha, \mathrm{n}-\mathrm{k}) 0,05 ; 5}=\quad-2.571$, maka dapat disimpulkan bahwa variabel BL mempengaruhi variabel Kemiskinan (JPM) secara signifikan pada tingkat kepercayaan 95\%. Pada Tabel Output Eviews Model Kemiskinan (lihat Lampiran 1) kolom "probability value" menunjukkan nilai 0.0305, ini berarti variabel Belanja Langsung (BL) berpengaruh terhadap Kemiskinan dan signifikan pada alpha $5 \%(0.05)$.

\section{Variabel Belanja Tidak Lansung (BTL)}

Dari hasil estimasi model Kemiskinan, maka diperoleh nilai t-statistik untuk variabel BTL yaitu sebesar 0.015. Apabila dibandingkan dengan nilai t tabel, maka dapat dilihat bahwa nilai t-hitung variabel ini lebih besar dari batas kiri t-tabelnya dengan ketentuan $\mathrm{df}_{(\alpha, \mathrm{n}-\mathrm{k})} 0,05 ; 9=2.571$, maka dapat disimpulkan bahwa variabel BTL tidak berpengaruh terhadap variabel JPM. Pada Tabel Output Eviews Model Kemiskinan (lihat Lampiran 2) kolom "probability value" menunjukkan nilai 0.9607, yang artinya tidak signifikan. Ini berarti variabel Belanja Tidak Langsung (BTL) tidak berpengaruh terhadap Kemiskinan.

\begin{tabular}{c|cccc|} 
Ho ditolak & Ho tidak ditolak & $\frac{1}{\text { Ho ditolak }}$ \\
\hline & -2.571 & -0.015 & 2.571
\end{tabular}

\section{Variabel Investasi Swasta (INV)}

Dari hasil estimasi model kemiskinan, maka diperoleh nilai t-statistik untuk variabel INV yaitu sebesar 0.876. Apabila dibandingkan dengan nilai $\mathrm{t}$ tabel, maka dapat dilihat bahwa nilai t-hitung variabel ini lebih besar dari batas kiri $\mathrm{t}$-tabelnya dengan ketentuan $\mathrm{df}_{(\alpha, n-k) 0,05 ; 9}=2.571$, maka dapat disimpulkan bahwa variabel INV tidak mempengaruhi variabel JPM. Pada Tabel Output Eviews Model Kemiskinan (lihat Lampiran 2) kolom "probability value" menunjukkan nilai 0.4211 , yang artinya tidak signifikan, Ini berarti variabel Investasi (INV) tidak berpengaruh terhadap Kemiskinan.

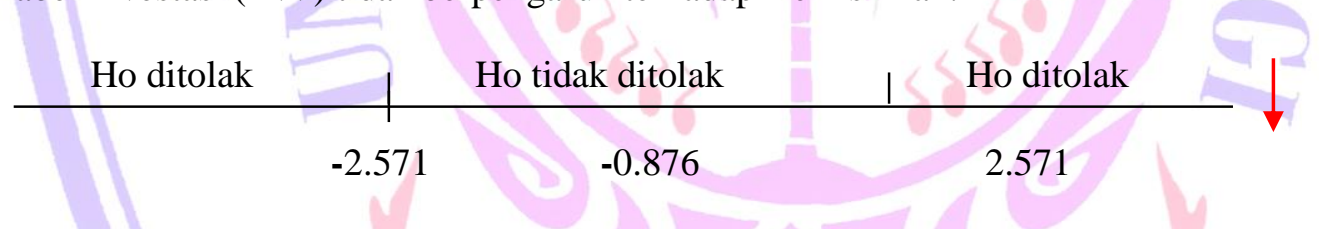

\section{Uji F-stat}

Uji F digunakan untuk mengetahui apakah variabel-variabel independen dalam persamaan regresi tersebut mempengaruhi variabel dependen secara bersamaan dengan tingkat signifikansi tertentu. Hipotesis dari uji ini adalah sebagai berikut,

$$
\text { Ho: } \beta 1=\beta 2=\beta 3=0
$$

(tidak ada pengaruh yang berarti antara variabel independen terhadap variabel dependen)

$$
\mathrm{Ha}: \beta 1, \beta 2, \beta 3 \neq 0
$$

(ada pengaruh variabel independen terhadap variabel dependen)

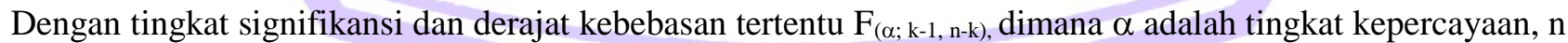
menunjukkan jumlah observasi dan $\mathrm{k}$ menunjukkan jumlah parameter termasuk konstanta, hasil pengujian akan menghasilkan kesimpulan menurut hipotesa diatas yaitu:

Ho tidak ditolak jika $\mathrm{F}_{\text {hitung }}<\mathrm{F}_{\text {tabel }}$

Ho tidak ditolak berarti variabel yang diuji secara keseluruhan tidak mempunyai pengaruh yang berarti terhadap pendapatan Kemisikinan.

Ho ditolak apabila $\mathrm{F}_{\text {hitung }}>\mathrm{F}_{\text {tabel }}$

Ho ditolak berarti variabel yang diuji secara keseluruhan mempunyai pengaruh yang berarti terhadap Kemiskinan. 
Berdasarkan hasil perhitungan yang telah dilakukan, diperoleh nilai $\mathrm{F}$ hitung/statistik sebesar 12.589. Jika nilai ini dibandingkan dengan nilai $\mathrm{F}$ tabel $\mathrm{l}_{(0.05, \mathrm{k}-1=3, \mathrm{n}-\mathrm{k}=9)}$ adalah 3.76 , maka diperoleh hasil bahwa nilai $\mathrm{F}$ hitung > F tabel, berarti Ho ditolak, hal ini berarti bahwa pada persamaan regresi model kemiskinan, variabel bebas (BL, BTL dan INV) secara bersama-sama berpengaruh terhadap kemiskinan (JPM).

\section{Koefisien Determinasi}

Dari hasil regresi yang dilakukan terhadap model kemiskinan (JPM) diperoleh hasil bahwa nilai $\mathrm{R}^{2}$ sebagai koefisien determinasi adalah 0.883. Hal ini menunjukkan bahwa variabel-variabel bebas pada persamaan tersebut, yaitu BL, BTL dan INV secara bersama-sama menerangkan $\pm 88 \%$ variasi dalam tingkat kemiskinan, sedangkan sisanya sebesar $\pm 12 \%$ dijelaskan oleh faktor-faktor lain di luar model.

\section{Uji Asumsi Klasik}

\section{Uji Normalitas}

Hasil Uji Normalitas dengan menggunakan Jarque-Berra Test (JB Test) ditunjukkan pada gambar 2. Hasil menunjukkan bahwa Model Kemiskinan dilihat dari Jarque-Bera normality statistic adalah sebesar 0.4759 lebih kecil dari nilai 2. Selain itu ditunjukkan juga oleh angka Probability sebesar 0.7882 yang lebih besar dari 0.05. Hal ini mebuktikan bahwa data telah berdistribusi normal (Pratomo, 2007).

Gambar 2 Uji Normalitas (Jarque-Bera Test)

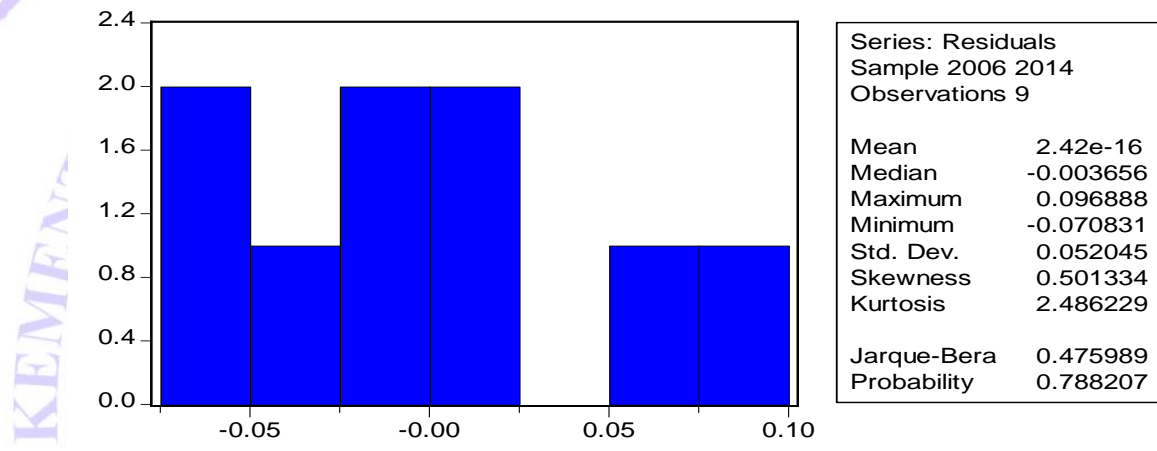

Sumber : Output Eviews

\section{Heteroskedastisitas}

Hasil Uji Heteroskedastisitas dengan menggunakan Uji White menunjukkan bahwa Model Kemiskiman tidak terdapat heteroskedastisitas. Hal tersebut dibuktikan dari hasil Uji White, dimana angka probabilita dari Obs*R-Squared pada hasil estimasi adalah lebih besar dari 0.05 yaitu sebesar 0.282762. Tabel 4.5. Menunjukkan hasil pengujian dengan Uji White.

\section{Tabel 1 Hasil Uji White}

\section{White Heteroskedasticity Test:}

\begin{tabular}{|c|c|c|c|}
\hline F-statistic & 1.579539 & Prob. $F(6,2)$ & 0.436968 \\
\hline Obs*R-squared & 7.431678 & Prob. Chi-Square(6) & 0.282762 \\
\hline
\end{tabular}

\section{Sumber : Output Eviews}

\section{Multikolinieritas}

Yang dimaksud dengan multikolinearitas adalah adanya hubungan linier diantara variabel-variabel bebas yang terdapat dalam suatu model. Widarjono (2006), Ciri-ciri adanya multikolinearitas dapat ditunjukkan oleh beberapa faktor, namun yang paling mendukung penjelasan adanya gejala multikolinearitas dalam model adalah jika dalam hasil regresi diperoleh nilai $\mathrm{R}^{2}$ yang tinggi (mendekati 1), tetapi tidak satupun atau sangat sedikit koefisien yang ditaksir penting secara statistik (melalui uji $\mathrm{F}$ dan uji t). Untuk mengetahui ada tidaknya multikolinearitas dapat digunakan melalui cara uji korelasi yaitu Coefficient Correlation Matrix, 
(Pratomo, 2007). Hal ini dapat dilihat pada tabel 2 tabel Coefficient Correlation Matrix. Tabel 2 menunjukkan bahwa antara variabel BL dengan BTL no multikol (nilai 0,77 kurang dari 0.80), dan BL dengan INV ada multikol (nilai 0,85 lebih besar dari 0.80) dan untuk BTL dengan INV terjadi multikol ( nilai 0,87 lebih besar dari 0,80 ).

Tabel 2 Coefficient Correlation Matrix

\begin{tabular}{|l|l|l|l|}
\hline & BL & BTL & INV \\
\hline BL & 1 & 0.769636 & 0.851298 \\
\hline BTL & 0.769636 & 1 & 0.870272 \\
\hline INV & 0.851298 & 0.870272 & 1 \\
\hline
\end{tabular}

Sumber : Output Eviews

\section{Otokorelasi}

Penaksiran model regresi linier normal klasik mengandung asumsi bahwa tidak terdapat korelasi serial diantara disturbance term atau autokorelasi, untuk menguji apakah dalam model tersebut terdapat autokorelasi dapat diuji dengan Uji Lagrange Multiplier (LM Test). Dari tabel 4.7 diperoleh hasil LM Test menunjukkan bahwa nilai probability 0.49846 lebih tinggi dari 0,05 . Hal ini berarti tidak terdapat otokorelasi dari hasil estimasi tersebut.

Tabel 3 Breusch-Godfrey Serial Correlation LM Test

\begin{tabular}{|lclc|}
\hline F-statistic & 0.27456 & Prob. F(2,3) & 0.77714 \\
Obs*R-squared & 1.39247 & Prob. Chi-Square(2) & 0.49846 \\
\hline
\end{tabular}

Sumber : Output Eviews

Interpretasi Ekonomi Model Kemiskinan (Jumlah Penduduk Miskin)

Dari hasil regresi persamaan model kemiskinan dapat diperoleh informasi mengenai pengaruh variabelvariabel bebas dalam persamaan tersebut terhadap variabel tak bebasnya. Dalam hal ini variabel tak bebas adalah Kemiskinan (JPM) dan sebagai variabel bebas yaitu Belanja Langsung (BL), Belanja Tidak Langsung (BTL) dan Investasi Swasta (INV). Nilai koefisien regresi pada masing-masing variabel bebas menunjukkan berapa besar pengaruh dari variabel bebas terhadap perubahan variabel tak bebasnya, ceteris paribus. Tanda positif yang menyertai koefisien regresi mengandung arti bahwa arah perubahan variabel bebas dan perubahan tak bebasnya berbanding lurus, sedangkan tanda negatif yang menyertai koefisien regresi mengandung arti bahwa arah perubahan variabel bebas dan variabel tak bebasnya berlawanan. Hasil regresi dari model kemiskinan di Kota Bitung ditunjukan persamaan 7.

$$
\text { LJPM = 11.1770 - 0.1941 LBL - 0.0075 LBTL - 0.0589 LINV . . }
$$

\section{Koefisien $\beta_{0}$ (Intercept / Konstanta)}

Koefisien $\beta_{0}$ memberikan (menggambarkan) pengaruh efek rata-rata semua faktor yang tidak dimasukkan ke dalam model kemiskinan. Secara mekanis ini adalah nilai Jumlah Penduduk Miskin saat nilai ketiga variabel bebas disamakan dengan nol. Ini menunjukkan bahwa tanpa adanya perubahan pada BL, BTL dan Investasi Swasta (INV), maka Jumlah Penduduk Miskin (JPM) untuk satu periode mendatang akan mengalami perubahan yang positif sebesar 11,1770 persen.

\section{Koefisien $\beta_{1}$ (variabel Belanja Langsung)}

Nilai koefisien sebesar - 0.1941 yang signifikan menunjukkan bahwa perkembangan Jumlah Penduduk Miskin (JPM) di Kota Bitung memiliki hubungan yang negatif dengan berubahnya Belanja Langsung (BL). Dengan perkataan lain, selama periode yang diteliti, dengan menjaga agar variabel-variabel lain tetap, 1 persen peningkatan dalam BL akan mengakibatkan pengurangan/penurunan rata-rata sekitar 0.1941 persen Jumlah Penduduk Miskin (JPM). Hasil ini sesuai dengan kaidah teori ekonomi dimana pengeluaran pemerintah akan mengurangi atau menurunkan tingkat kemiskinan atau jumlah penduduk miskin. Semakin besar belanja daerah diharapkan akan makin meningkatkan kegiatan perekonomian daerah (terjadi ekspansi 
perekonomian) dan pada akhirnya akan meningkatkan kesejahteraan masyarakat dan tentunya akan mengurangi kemiskinan.

\section{Koefisien $\beta_{2}$ (variabel Belanja Tidak Langsung)}

Nilai koefisien sebesar - 0.0075, menunjukkan bahwa perkembangan jumlah penduduk miskin (JPM) di Kota Bitung memiliki hubungan yang negatif dengan meningkatnya BTL. Dengan perkataan lain, selama periode penelitian, dengan menjaga agar variabel-variabel lain tetap (ceteris paribus), 1 persen peningkatan dalam BTL akan mengakibatkan penurunan rata-rata sekitar 0.0075 persen dalam JPM.

Hasil ini sesuai dengan kaidah teori ekonomi dimana pengeluaran pemerintah akan mengurangi atau menurunkan tingkat kemiskinan atau jumlah penduduk miskin. Semakin besar belanja daerah diharapkan akan makin meningkatkan kegiatan perekonomian daerah (terjadi ekspansi perekonomian) dan pada akhirnya akan meningkatkan kesejahteraan masyarakat dan tentunya akan mengurangi kemiskinan. Akan tetapi dalam penelitian ini BTL pengaruhnya terhadap JPM tidaklah signifikan secara statistik.

\section{Koefisien $\beta_{3}$ (variabel Investasi Swasta)}

Nilai koefisien sebesar - 0.0589 menunjukkan bahwa JPM di Kota Bitung memiliki hubungan yang negatif dengan bertambahnya Investasi swasta (INV). Hal ini menunjukkan bahwa dengan bertambahnya INV akan mengurangi Kemiskinan (JPM) di Kota Bitung. Dengan perkataan lain, selama periode penelitian, dengan menjaga agar variabel-variabel lain tetap, 1 persen peningkatan dalam INV akan mengakibatkan penurunan rata-rata sekitar 0.0589 persen JPM di Kota Bitung.

Hasil ini sesuai dengan kaidah teori ekonomi dimana peningkatan Investasi swasta akan mengurangi tingkat kemiskinan atau jumlah penduduk miskin. Semakin besar Investasi swasta (INV) diharapkan akan makin meningkatkan kegiatan perekonomian daerah (terjadi ekspansi perekonomian) dan pada akhirnya akan meningkatkan kesejahteraan masyarakat dan tentunya akan mengurangi kemiskinan. Akan tetapi dalam penelitian ini INV pengaruhnya terhadap JPM tidaklah signifikan secara statistik.

\section{KESIMPULAN DAN SARAN}

Berdasarkan pada teori-teori dan pembuktian baik secara empiris maupun ekonomi mengenai pengaruh Belanja Langsung, Belanja Tidak Langsung, dan Investasi Swasta terhadap kemiskinan di Kota Bitung pada tahun anggaran 2006 sampai dengan tahun 2014, maka dapat ditarik kesimpulan dan saran sebagai berikut.

\section{Kesimpulan}

1. Belanja Langsung, Belanja Tidak Langsung dan Investasi swasta ternyata mempunyai hubungan yang terbalik dengan kemiskinan.

2. Belanja Langsung Pemerintah Kota Bitung secara signifikan mampu mengurangi Jumlah Penduduk Miskin Kota Bitung.

3. Belanja Tidak Langsung dan Investasi Swasta tidak siginifikan secara statisitik dalam mereduksi kemiskinan di Kota Bitung.

Saran

1. Mengingat Belanja Langsung Pemerintah Kota Bitung sangat berperan dalam mereduksi Jumlah Penduduk Miskin, maka dalam pengelolaan keuangan daerah antara belanja langsung dengan belanja tidak langsung, proporsi belanja langsung haruslah lebih besar dari belanja tidak langsung.

2. Mengingat hasil penelitian ini menunjukan bahwa investasi tidak berpengaruh secara siginifikan dalam mengurangi kemiskinan di kota Bitung, maka penulis berasumsi investasi di kota Bitung tidak padat karya, sehingga dipandang perlu pemerintah daerah untuk membuat kebijakan investasi yang padat karya.

\section{DAFTAR PUSTAKA}

Anna Yulianita dan Ratna Juwita. 2009, Pengaruh Pengeluaran Pemerintah terhadap Angka Kemiskinan di Sumatera Selatan 
Anthony Shorrocks and Rolph van der Hoeven. 2004, "Growth, Inequality, and Poverty Economic Policy, Distribution, and Poverty: The Nature of Disagreements

Arsyad, Lincolin, 1999. Pengantar Perencanaan dan Pembangunan Ekonomi Daerah, BPFE, Yogyakarta.

Adhisasmita. 2005. Analisis Kesenjangan Pembangunan Regional : Indonesia 1992-2004. Jurnal Ekonomi Pembangunan Kajian Ekonomi Negara Berkembang, Vol. 9, No. 2, Hal: 129-142

Badan Pusat Statistik Kota Bitung. Bitung Dalam Angka 2005-2014

Barika, 2013 Pengaruh Pertumbuhan Ekonomi, Pengeluaran Pemerintah, Pengangguran dan Inflasi terhadap tingkat kemiskinan di Provinsi Se Sumatra, Jurnal Ekonomi dan Perencanaan Pembangunan Volume:05 No.01, Januari-Juni 2013

Blakley, Edward, J. (1994). Planning Lokal Economic Development. Theory and Practice, Second Edition, USA, Sage Publikation, Inc, california.

Bjornestad, Liv, 2009, Fiscal Decentralization, Fiscal Incentives, and Pro-Poor Outcomes: Evidence from Vietnam, ADB Economic Working Series No.168, Asian Development Bank.

Boex, Jameson, dkk, 2006, Fighting Poverty Through Fiscal Decentralization.

Camilla Mastromarco, 2014 "Poverty, inequality and growth in Albania" economic of transition

Christine Martha Sihotang Marsoit, Rosalina Koleangan dan Richard Tumilaar, pengaruh investasi swasta dan belanja modal terhadap kemiskinan di kota manado tahun 2004-2012. ejournal.unsrat.ac.id

Desy Suryati. 2015, Pengaruh belanja daerah berdasarkan klasifikasi ekonomi terhadap pengentasan kemiskinan dan indeks pembangunan manusia di kabupaten/kota provinsi nusa tenggara barat tahun 2007-2012. Media Bina Ilmiah, Volumen 9 No 7 Tahun 2015.

Dumairy, MA.1996. Perekonomian Indonesia. Penerbit Erlangga. Jakarta

Haryanto, Tommy Prio. 2013. Pengaruh Pengeluaran Pemerintah Terhadap Pertumbuhan Ekonomi Kabupaten/Kota di Provinsi Jawa Tengah Tahun 2007-2011. Jurnal Ekonomi. Jurusan Ekonomi Pembangunan Fakultas Ekonomi Universitas Negeri Semarang

Junaidi Momongan, 2013 Investasi PMA dan PMDN pengaruhnya terhadap perkembangan PDRB dan penyerapan tenaga kerja serta penaggulangan kemiskinan di Sulawesi Utara

Jhingan, M.L, (1993). Ekonomi Pembangunan dan Perencanaan, PT Raja Grafindo Persada, Jakarta

Kementrian Keuangan Republik Indonesia (2004) Laporan Pelaksanaan Spending Performance dalam mendanai pelayanan publik

Kuncoro, Mudrajad. 2004. Otonomi dan Pembangunan Daerah, Reformasi, Perencanaan, Strategi dan Peluang. Jakarta: Airlangga

Mangkoesoebroto, Guritno.2001.Ekonomi Publik, BPFE, Yogyakarta

Mankiw, N.Gregory.2000.Teori Makro Ekonomi.Ed.4, Jakarta: Penerbit Erlangga.

Mehmood, R and S. Sadiq. 2010. The Relationship beetween Government Expenditure and Poverty: A Cointegration Analysis. Romanian Journal of Fiscal Policy, 1(1) : 29-37.

Merdekawati, Inggar Putri an Budiantara, Ketut. 2013. Pemodelan Regresi Spline Truncated Multivariabel Pada Faktor-Faktor yang Mempengaruhi Kemiskinan di Kabupaten/Kota Provinsi Jawa Tengah. Jurnal Sains Dan Seni Pomits Vol. 2, No.1, (2013) 2337-352.

Norman V. Loayza, Claudio Radat (2009) "The composition of growth matter for poverty alleviation" Journal of Development Economics

Rahayu, S. A. T. 2004. "Peranan Sektor Publik Lokal dan Pertumbuhan Ekonomi Regional di Wilayah Surakarta Tahun 1987-2000". Jurnal Kinerja. Volume 8 (2): 133-147.

Rahma Amali, 2015 Pengaruh Pengeluaran Pemerintah Terhadap Kemiskinan Di Provinsi Sulawesi Barat (2007-2013).

Rudi wahyudi. 2014, Analisis Pengaruh Belanja Pemerintah Dan Pertumbuhan Ekonomi Terhadap Tingkat Kemiskinan Di Aceh.

Samuelson, Paul A dan William D.Nordhaus.1996. Makro Ekonomi (terjemahan). Edisi keempatbelas, Erlangga,Jakarta.

Santosa, Budi. 2013. Pengaruh Pendapatan Asli Daerah dan Dana Perimbangan daerah Terhadap Pertumbuhan, Pengangguran dan Kemiskinan 33 Provinsi di Indonesia. Jurnal Ekonomi dan Bisnis. Vol. 5, No. 2 Juli 2013. 
Shenggen, F. and P. Hazell. 2001. Returns to Public Investments in The Less-Favored Areas of India and China. American Journal of Agricultural Economics, 83 : 1217-1222.

Sepulveda, Cristian F., 2010, The Consequences of Fiscal Decentralization on Poverty and Inequality, George State University.

Sinegar, Hermanto dan Wahyuniarti, Dwi. 2006. Dampak Pertumbuhan Ekonomi Terhadap Penurunan Jumlah Penduduk Miskin

Siregar, Hermanto. 2006. "Perbaikan Struktur dan Pertumbuhan Ekonomi: Mendorong Investasi dan Menciptakan Lapangan Kerja", Jurnal Ekonomi Politik dan Keuangan, INDEF, Jakarta.

Suliswanto, Muhammad Sri Wahyudi. 2010. Pengaruh Produk Domestik Bruto (PDB) dan Indeks Pembangunan Manusia (IPM) Terhadap Angka Kemiskinan di Indonesia. Jurnal Ekonomi Pembangunan, Vol 8 No. 2 Desember 2010.

Sukirno, Sadono. 2011. Makro Ekonomi Teori Pengantar. PT. Raja Grafindo Perkasa . Jakarta.

Suryadarma, D. dan A. Suryahadi. 2007. The Impact of Private Growth Sector on Poverty eduction: Evidence from Indonesia. SMERU Working Paper, April 2007.

Skira, Meghan, 2006, Fiscal Decentralization and Poverty, Andrew Young School of Policy Studies

Todaro, M. P. dan Stephen C. Smith. Pembangunan Ekonomi. 2008. Jakarta: Erlangga.

Vera Wilhelm and Ignacio Fiestas, 2005, Exploring the Link Between Public Spending and Poverty Reduction: Lessons from the 90s, The International Bank for Reconstruction and Development/The World Bank, Washington DC.

Wong, John D. 2004. The Fiscal Impact of Economic Growth and Development on Local Government Revenue Capacity. J.Of Public Budgeting, Accounting \& Financial Management, 16(3), 413-423.

Widodo, Adi, Waridin Dan Maria K., Johanna. 2011. Analisis Pengaruh Pengeluaran Pemerintah Di Sektor Pendidikan Dan Kesehatan Terhadap Pengentasan Kemiskinan Melalui Peningkatan Pembangunan Manusia Di Provinsi Jawa Tengah. Jurnal Dinamika Ekonomi Pembangunan, Vol. 1.

Yao, Guevera Assamoi, 2007, Fiscal Decentralization and Poverty Reduction Outcomes: Theory and Evidence, George State University.

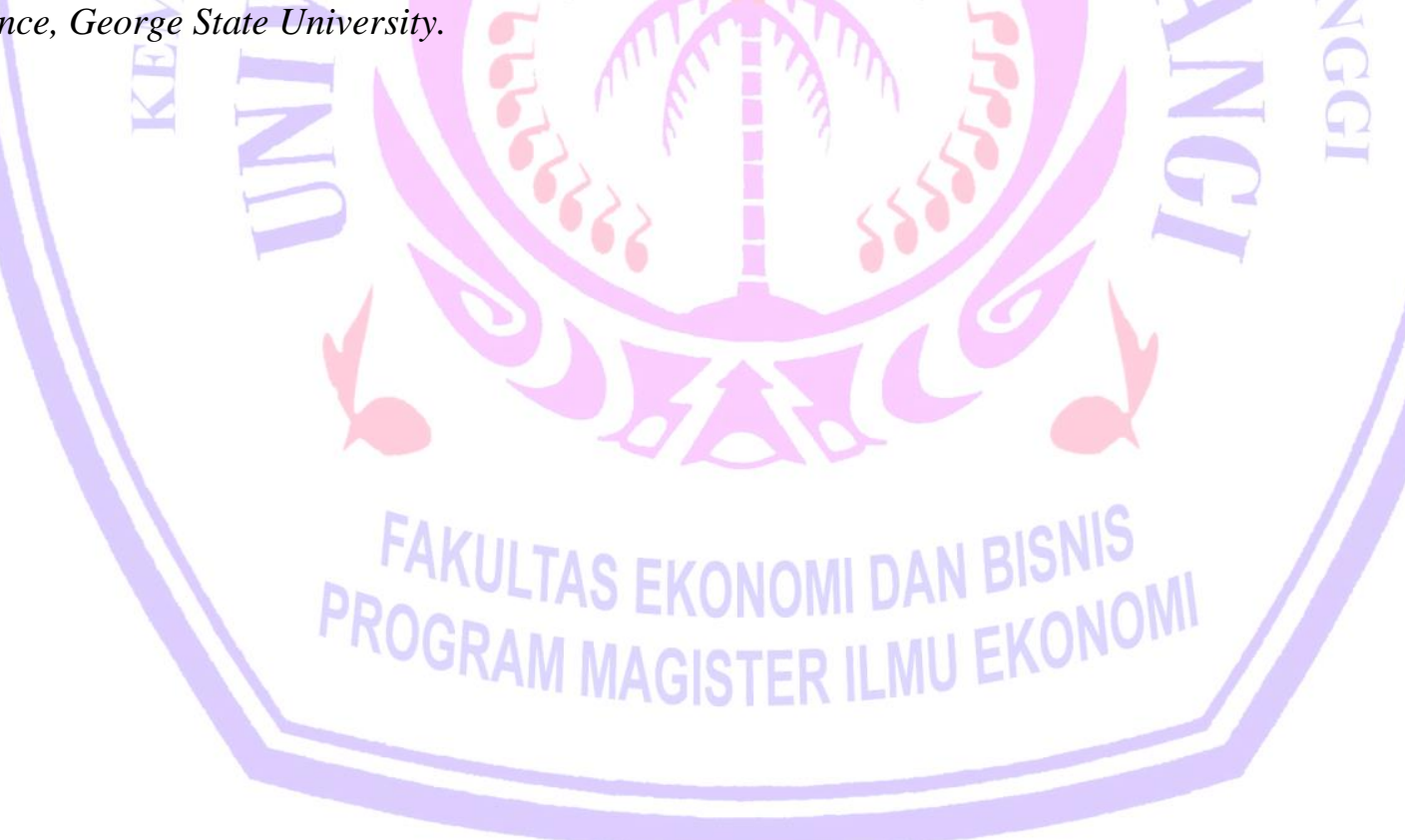

